PRI Discussion Paper Series (No.20A-15)

Do fiscal policy news shocks affect JGB yield? Evidence from COVID-19

Corresponding author. Project Assistant Professor, University of Tokyo and

Visiting Scholar, Policy Research Institute, Ministry of Finance, Japan

Takahiro Hattori

Visiting Scholar, Policy Research Institute, Ministry of Finance, Japan

Motoki Katano

December 2020

The views expressed in this paper are those of the authors and not those of the Ministry of Finance or the Policy Research Institute.

Research Department Policy Research Institute, MOF

3-1-1 Kasumigaseki, Chiyoda-ku, Tokyo 100-8940, Japan

TEL 03-3581-4111 


\title{
Do fiscal policy news shocks affect JGB yield? Evidence from COVID-19*
}

\author{
Takahiro Hattori ${ }^{\dagger}$ and Motoki Katano ${ }^{\ddagger}$
}

December 2020

\begin{abstract}
This is a pioneering study that investigates how fiscal news affects the yield of the Japanese Government Bond (JGB), by using intraday data. Since the Japanese government is the largest spender in the world, during the COVID-19 pandemic, this period provides the ideal situation or setting to test how fiscal news affects JGB yield. Taking advantage of the minute by minute data about fiscal news during this pandemic, we find that negative fiscal news significantly but temporarily increased JGB yield, although it is not a persistent effect. We also find that investors do care about negative news but not about the positive news. These results suggest that the JGB is considered a risk-free asset among investors, but the result also signals to the Japanese government to work on sound management of debt sustainability from a long-term perspective.
\end{abstract}

JEL codes: E62, H62, H63

Keywords: Budget Deficit, Japanese Government Bond, Interest Rate, Fiscal News, COVID-19

\footnotetext{
* We would like to thank Makoto Hasegawa, Kengo Kameda, Hiroshi Morita, Wataru Sakata, Junji Ueda and the seminar participants at Kansai public economics seminar and Ministry of Finance, Japan for their helpful comments. Motoki Katano handled the construction of the fiscal news index and section 2. Takahiro Hattori owns the research design/idea and the other sections (Introduction and Sections 3-5). The views expressed herein are those of the authors and do not necessarily reflect the opinions of the organizations to which the authors belong. Any remaining errors are the sole responsibility of the authors.

† Corresponding author. Project Assistant Professor, University of Tokyo and Visiting Scholar, Policy Research Institute, Ministry of Finance, Japan. hattori0819@gmail.com.

‡ Visiting Scholar, Policy Research Institute, Ministry of Finance, Japan. motoki.fujimori@gmail.com
} 


\section{ノンテクニカル・サマリー}

東京大学 公共政策大学院 特任講師、財務省 財務総合政策研究所 客員研究員 服部孝洋 財務省 財務総合政策研究所 客員研究員 片野幹

日本は長年財政支出が拡大し財政赤字が累積する一方、日本国債の金利は総じて低迷している。そ のため、一見すると財政支出と金利の関係には財政学の教科書にあるような正の関係 (財政支出によ り金利が上昇するという関係）が見られない。もっとも、財政支出が拡大する時期は主に景気の悪化 局面であること、日銀による国債の買い支えや安全資産に対するニーズの増加局面でもあること等 を踏まえると、財政支出と金利の時系列について単純にそれらの相関関係を見るだけで因果関係を 指摘するのは不適切であり、財政支出が金利に対してどのように影響を与えたのかを推定するには 一定の工夫が必要である。

本稿では、Covid-19 の経済対策として行われた累次の財政支出が日本国債の金利に与える影響に ついて、財政支出に係るニュースデータを用いて、財政支出と金利の間にある因果関係を推論する。 本稿のアイデアは分刻みの金利データを用い、財政支出に係るニュースが報じられたタイミングで、 金利がどのような動きをしているかを把握するというものである。市場が効率的であれば金利や先 物価格に既存の情報は反映されていると解釈できる。そのため、新しい財政ニュースが出た瞬間に金 利がどのように動いているかをみることで、財政ニュースが金利に与えている影響を把握すること が可能になる。テクニカルには、財政支出に係るニュースが、市場関係者にとって新しい情報である とすれば、ニュースと誤差項の相関はなく、財政が金利に与える効果について因果推論ができる。

本稿では令和 2 年度補正予算の議論が開始された 2020 年 3 月以降のニュースデータを、Bloomberg から特定化し、財政ニュース指数を構築したうえで、その指数と金利を用いた回帰分析を行う。財政 ニュース指数については Kameda (2019)による手法に則る。既存研究に対して、筆者らの研究は、先 行研究の研究に対して、(1)日中のデータをベースに財政ニュースを活用しており、識別の点で改善が みられること、(2)経済学者や実務家に関心が高い Covid-19 の影響を分析しているという点で新規性 を有する。

筆者らの発見は、(1)財政に対して負のニュースが出た場合、10 年金利が上がる（先物価格が下が る)ことを統計的に有意な形で見出したこと、(2)もっともその効果は小さく、その持続性も小さい可 能性がある、という点である。その意味では、日本国債は安全資産として投資家に認識されているこ とを示す結果である。もっとも、財政に関する負のニュースが金利上昇に統計的に有意な影響を与え ていることは、財政悪化に対して投資家は一定の懸念を示す結果と解釈することも可能である。 


\section{Introduction}

This paper challenges the classical issues which Japanese economists have long pursued. Does fiscal deficit increase the Japanese Government Bond (JGB) yield? Economists have been warning the government about the deterioration of the fiscal deficit and government debt levels, but inexplicably, the JGB yield continues to decline. Especially after the 1990s, government debt increased dramatically, and the debt to GDP ratio reached over $200 \%$. One of the myths related to the Japanese government deficit is the negative trend of the nominal interest in the JGB market after the 1990s. Figure 1 shows the ten-year JGB yield and outstanding government debt, which indicates that JGB yield continues to decrease even as public debt increases. If the JGB yield reflects the default risk of JGBs, the increase of government debt should have increased the JGB yield accordingly.

One of the mechanisms describing this paradoxical phenomenon relies on the endogeneity between interest rates and government deficits. As Figure 1 shows, the Japanese government deficit started to increase sharply from the 1990s, which coincided with the Japanese recession, which earned it the moniker of, The Lost Decade. While the government faced a recession, it stimulated the economy by increasing government spending. Simultaneously, to boost the economy, the Bank of Japan (BOJ) also cut interest rates which exerted negative pressure on the nominal interest rate. Therefore, it is not surprising that the JGB yield declines while the government continues to increase government deficit in conjunction with the BOJ's accommodative monetary policy.

To challenge this endogeneity, we use high-frequency data and fiscal news to detect the causal relationship between JGB yield and fiscal deficits. By utilizing high-frequency data and surprise, 
many papers have attempted to study and detect how the asset price reacts to new information releases (see Hashimoto and Ito (2010)). If we construct the fiscal news minute by minute, we can detect how the ten-year JGB yield has responded to fiscal news. In terms of monetary policy, the BOJ announces the detailed schedule of purchasing JGBs under the Quantitative and Qualitative Monetary Easing, in advance; therefore, information related to monetary policy should be immediately impact the ten-year JGB yield on the assumption of market efficiency. ${ }^{1}$ In other words, if the JGB yield responds immediately to the fiscal news, we can identify this response to be caused by the fiscal news, not by the news on monetary policy.

Following Kameda (2019) to construct the fiscal news index, we regress the ten-year JGB yield to the fiscal news index. We find that negative fiscal news has a positive (negative) effect on the ten-year JGB yield (JGB futures price), which is consistent with previous studies such as Kameda (2014, 2019). Our result indicates that investors do care about the fiscal condition for pricing JGB, which is a warning for the Japanese government to soundly manage their debt sustainability. Conversely, since negative fiscal news does not have a persistent effect on the ten-year JGB yield (JGB futures price), this result suggests that investors currently consider JGBs as a risk-free asset. Moreover, we find that the negative news increases the yield but the positive news does not affect it, suggesting that the investors only care about or react to negative news.

For constructing the fiscal news index, we use the fiscal events during the COVID-19 pandemic. As a matter of fact, Japan is the largest fiscal spender in the world during this period. In this respect, the COVID-19 period provides an ideal opportunity to explore how much fiscal shock affects the JGB yield. It was not easy, but we successfully obtained the intraday data of the ten-year JGB yield

\footnotetext{
1 See Hattori (2020) for detail about Quantitative and Qualitative Monetary Easing.
} 
during this period from Bloomberg.

Our result is robust even when we include controlling variables. Especially controlling for stock prices is vital—even if government spending increases JGB yield, investors might interpret that the fiscal expansion will positively affect the Japanese economy—-therefore, this might increase inflation expectation. To control this effect, we include the intraday data of stock return. Specifically, if investors interpret the government spending as measures to improve the economy, this will also increase stock prices. We show our result to be robust even when we include stock return as the control variable.

Literature Review: There are many papers which discuss the relationship between fiscal deficit and interest rates. The early studies (Plosser (1982), Evans $(1985,1986))$ discuss deficits that cause lower interest rates, which is theoretically a surprising result. One strand of the literature focuses on media-reported budget news. By taking advantage of the expectation of the Congressional Budget Office (CBO), Wachtel and Young (1987) find that the announcement of fiscal deficits increases interest rates in the US. Quigley and Porter-Hudak (1994) study over 300 deficit project reports contained in the Wall Street Journal to expand on the work of Wachtel and Young (1987) and conclude that the fiscal deficit causes an increase in interest rates. Kitchen (1996) shows similar results, while also showing that the deficit effect is transmitted internationally with foreign long-term interest rates, which also rise in response to the announced increases in US deficit projections.

Compared to the literature using US data, there are fewer papers focusing on the relationship between the fiscal news and interest rates in Japan. Nakazawa (2002) points out that government deficits significantly affect long-term interest rates by using VAR methodology. Onji et al. (2012) 
show that the presence of the Japanese public sector as a large stable investor in JGBs, exerts a stabilizing influence on private JGB traders, and the default risk of JGBs is negligible. Kameda (2014) uses the event study methodology and finds that a percentage point increase in both the projected/current deficit-to-GDP ratio and projected/current primary-deficit-to-GDP ratio, raise real ten-year interest rates by 26-34 basis points. The work of Kameda (2019) is most closely related to our study and it constructs the daily based news index to show a negative relationship between the ten-year JGB yield and the fiscal news index.

The difference between previous studies and our study is threefold. First, we use intraday data to discuss the relationship between fiscal conditions and nominal interest rates. As described previously, an intra-day analysis is essential for capturing the causal relationship. We show results consistent with previous studies; therefore, our paper reinforces the literature. Second, we find that fiscal news significantly affects the rate of change of the ten-year JGB yield (return of JGB futures price), although Kameda (2019) pursues the long-run relationship between fiscal news and the level of the ten-year JGB. In most studies based on news or surprise, the economist uses the return on the financial asset (instead of the price level of the financial asset) as the dependent variable; thus our study utilizes the standard model to detect and evaluate the relationship between the fiscal deficit and interest rates. Third, to the best of our knowledge, this is the first empirical research that investigates fiscal policy during the COVID-19 pandemic. Considering the persistence of the pandemic, the Japanese government might pursue additional government spending; therefore, our result provides policy implications for the financing of that expenditure by issuing additional JGBs to stimulate the economy.

The remainder of this paper is organized as follows. Section 2 describes the institutional 
background and fiscal news data. Section 3 discusses the model and our data. Section 4 shows the empirical results and robustness checks. Section 5 concludes.

\section{Institutional background and fiscal news data}

\subsection{Japan's government spending to cope with COVID-19}

First, we describe the government budget process in Japan. The Constitution and the Public Finance Law provide the principles for the budget compilation process. Each initial budget must be suggested and decided by the cabinet and then approved by the Diet for every fiscal year, which runs from April 1 to March 31. The government can revise the initial budget during the fiscal year, and this supplementary budget has to be adopted by the Diet as well. Figure 2 is a simple depiction of the supplementary budgets process. Following the Prime Minister's declaration, the draft budget is sent for compilation by the Ministry of Finance, which is the general authority for budget formulation in place of the cabinet. Afterwards, it is approved and submitted as a bill to the Diet by the cabinet. Then, the House of Representatives (Lower House) discuss the bill and pass it to the House of Councilors (Upper House) for further discussion. After the Upper House passes the bill, the budget is finally enacted (Doi and Ihori, 2009).

Due to the nationwide spread of COVID-19, Prime Minister Abe declared a state of emergency on April 7 for Tokyo and six other prefectures and later extended it to the whole nation. The government requested people to stay home and for nonessential businesses to suspend operations, dealing a harsh blow to the economy. The state of emergency was lifted fully on May 25, 2020 and unfortunately, many areas have since seen a resurgence in infection rates.

The COVID-19 crisis has already delivered various shocks to Japan. Fukui et al. (2020) and 
Kikuchi et al. (2020) have argued the impact of COVID-19 on the labor market. Miyakawa et al. (2020) quantified firms' potential exits and the additional measures required in response to COVID-19. From the perspective of consumption, a detailed study on increasing online consumption was made by Watanabe and Omori (2020).

As Ando et al. (2020) showed in detail, Japan's government enacted two consecutive supplementary budgets for FY2020 in response to COVID-19, which focused on supporting firms, workers, and households, and then shifted to long-run support for business and healthcare services. They consist of urgent comprehensive grants for health and medical services, subsidies for employment protection and business continuity, cash transfer for residents, etc.

We should highlight the three largest fiscal measures, financial support of firms, the Special Cash Payment and contingency funds for COVID-19; the amount of which is approximately $70 \%$ of the two supplementary budgets. First, the government enhanced financial support for small and medium-sized enterprises that were badly affected by this emergency, totaling about 15.5 billion yen. Second, the Special Cash Payments with a budget of around 12.9 billion yen, was an unconditional cash transfer of 100,000 JPY per Japanese resident. Third, 11.5 billion yen was allocated to reserves for an emergency fund, from which the cabinet can flexibly spend, but with subsequent approval of the Diet for all payments. The supplementary budget also included benefits for small businesses, at risk of permanent closure with a budget of about 6.3 billion yen, a special grant for revitalization of regions with a budget of 3 billion yen, and the Comprehensive Support Grant for healthcare with a budget amounting to over 2.9 billion yen. ${ }^{2}$

As mentioned above, the supplementary budgets for the stimulus policy were adopted in a short

\footnotetext{
2 See Fiscal System Council, the presentation on October 1, 2020 (in Japanese)
} 
period. The detailed schedule of the first and second supplementary budget processes are shown in Figure 3, which should be compared with Figure 2. The general flow of the process is almost the same between both supplementary budgets, however, it should be emphasized that the first supplementary budget draft was changed after the cabinet decided on it, and it was finally approved on April 20. ${ }^{3}$

\subsection{The fiscal situation during COVID-19}

Here we examine the current fiscal situation in response to COVID-19 in Japan. The first supplementary budget is worth 25.7 trillion yen, and the second is 31.9 trillion yen within a short period, which in total is the largest scale intervention since 1945. In combination with a part of the main budget, the total spending exceeded 230 million yen in scale, which is an unprecedented 40 percent of GDP, the most extensive worldwide. ${ }^{4}$ Figure 4 summarizes the international comparison of the scale of government spending in response to COVID-19 among the G5 countries at the end of May 2020, showing that Japan was the largest spender. With respect to revenues, however, as is well known, Japan's fiscal condition is the worst among the developed countries. This time, all the supplementary budget expenditures are covered by JGBs, named the special deficit-financing bond (deficit bond). Hence, the bond dependency ratio, defined as the ratio of government bond issues to total expenditures in the annual general accounts, reached $56.3 \%$ in FY2020. In Figure 5, it is clearly observed that the gap of expenditure and revenue lines, which

\footnotetext{
3 The composition of the budget was changed because some members in the ruling party demanded a special cash payment of 100,000 yen, once after cabinet approved the draft budget on April 7.

${ }^{4}$ It includes not only expenditures in supplementary budgets expenditure but also liquidity support surpassing 130 trillion yen, such as subordinated loans or investment from the Development Bank of Japan, and loans that are interest free in real terms with principal repayment deferred for a maximum of five years from local and government banks.
} 
mostly equals the quantity of bond issuance, has been gradually widened, and there is a marked increase in FY2020, including the first and second supplementary budgets.

From the above, two critical points become very clear. One is that Japan's spending against COVID-19 is the largest scale globally. The other is that such huge expenditures were made, depending entirely on issuing government bonds, and this impacted the JGB market. This setting therefore provides an ideal opportunity to explore how much fiscal shock affects the JGB rate.

\subsection{Fiscal news data}

To construct the fiscal news index, we follow Kameda (2019), who employs daily data from the morning and evening editions of the Nikkei Telecon 21. The limitation of Kameda's (2019) study is that it captures the effect of fiscal news on JGB yield on a daily basis. However, a variety of news is released each day; therefore, if we use daily news, the impact of non-fiscal news may also be reflected in the asset price.

To overcome this issue, we selected Bloomberg as the source of fiscal news. Bloomberg assembles the news from a variety of sources, including major newspapers such as Nikkei, which is known as the largest financial newspaper in Japan. Moreover, this source also includes Bloomberg News, which is widely recognized by institutional investors. ${ }^{5}$ The greatest benefit of using Bloomberg is that this source provides minute by minute news and updates. Since printed newspaper articles are issued only in the morning and evening, this traditional source cannot capture updated news in real-time. As far as we know, this study is the first to utilize minute by minute fiscal news data to investigate the impact of fiscal shock on JGB yields.

\footnotetext{
5 At the end of 2019, private investors held a small share of JGB, only 1.2\%. Therefore, we can focus on the way market participants obtain information.
} 
The methodology of the fiscal news index

To construct the fiscal news index, we follow the methodology proposed by Kameda (2019). Kameda (2019) constructs the fiscal news index based on the number of positive and negative articles. Since Kameda (2019) uses the daily based index, he first judges what article is positive or negative for the fiscal condition of the Japanese government; then the fiscal news index is defined as the number of positive articles minus the number of negative articles. Following the same idea, we construct the fiscal news index as follows:

Fiscal News Index $t=1$ if the fiscal news is positive

Fiscal News Index ${ }_{t}=-1$ if the fiscal news is negative

When the fiscal news is positive for the fiscal condition of the Japanese government, the fiscal news index takes 1 . On the other hand, when the fiscal news is negative for the fiscal condition, the fiscal news index takes -1 . When there is no fiscal news, this index takes zero.

Keywords for the fiscal news index

To find fiscal news, we searched for the relevant headlines from March to July in 2020, to construct the database for a fiscal shock in Japan. To collect the news from the headlines, we use the following keywords:

(i) Keizai-Taisaku (Economic Measures)

(ii) Kinkyu-Taisaku (Emergency Measures) 
(iii) Kyufu-Kin (Benefits)

(iv) Yobi-hi (A Reserve Fund in the National Budget)

(v) Hosei-Yosan (Supplementary Budget)

Conversely, we drop irrelevant news data based on the following criteria:

(a) Fiscal news which is not related to Japan;

(b) News from curation sites such as "Yahoo! News” or "Livedoor News";

(c) Market comments from economists or financial analysts, who are not political decision-makers;

(d) Duplicate data from the same media.

Figure 6 shows the number of fiscal news headlines from March to July. The remarkable feature of this index is the capability to successfully capture the two supplementary budget processes, especially around the critical event schedule described in Figure 5. In addition, the severity of the COVID-19 impact on the Japanese economy is fluctuating, and new decisions are taken minute by minute by the Japanese government. Therefore, as Figure 7 describes it, we emphasize that the fiscal news was released anytime during the 24 hours of a day. Since we capture fiscal news during the night as well, our analysis relies not only on ten-year JGBs but also JGB futures, which are traded at night.

\section{Model and data}

\subsection{Model}

To detect how fiscal news affects the JGB market, we estimate the following regression: 


$$
y_{t}=\alpha+\beta \cdot N e w s_{t}+\varepsilon_{t}
$$

$y_{t}$ is the difference of ten-year JGB yield and the return of JGB futures. $N e w s_{t}$ is the fiscal news index which we describe in section 2.2. $\varepsilon_{t}$ is an error term.

To capture the persistence of the news effect, we conduct the regression separately over 1-, 5-, 15-, 30-, and 60-minute windows in equation (1). $y_{t}$ is the 1-, 5-, 15-, 30-, and 60-minute return of the ten-year JGB yield and JGB futures.

To check whether good or bad fiscal news has a heterogeneous effect on the return of ten-year yield and JGB futures, we use the equation as below:

$$
y_{t}=\beta \cdot \operatorname{GoodNews}_{t}+\gamma \cdot \text { BadNews }_{t}+\varepsilon_{t}
$$

GoodNews $_{t}$ is the dummy variable when the fiscal news is positive. BadNews $t$ is the dummy variable when the fiscal news is negative. ${ }^{6}$

Fiscal news could affect the JGB price through different channels. Especially, when the government increases spending for stimulating the economy, this could positively affect the macroeconomy. This could increase economic growth and expected inflation, which hikes the nominal interest rate. To control this effect, we include Control $_{t}$ in equation (1) as below:

$$
y_{t}=\alpha+\beta \cdot \text { News }_{t}+\gamma \cdot \text { Control }_{t}+\varepsilon_{t} .
$$

\footnotetext{
6 The constant term is dropped to avoid multicollinearity.
} 
We include stock return as a control variable. If the investors interpret that government spending will boost the economy, the stock price should increase; therefore, this variable can capture the aspect of economic growth and expected return. We also control the foreign exchange rate (USD/JPY) for robustness.

\subsection{The data}

Our data source is based on Bloomberg as mentioned in section 2.3. It is usually very difficult to obtain intraday data on the JGBs, which are traded in the over-the-counter market. However, Bloomberg provides intraday data for ten-year JGBs, and also preserves the data for short periods.

The data from Bloomberg only covers timings of 9:00 to 17:00 for ten-year JGBs; therefore, we cannot capture the minute by minute response of ten-year JGBs to fiscal news released in the nighttime. On the other hand, JGB futures are traded in the night. For JGB futures, the night session is from 15:30 to 5:25 (the next day). Therefore, we use the return of JGB futures as our main analysis. We also use the intraday data of ten-year JGBs.

We match the difference of the ten-year JGB yield with the time of the fiscal news release. For ten-year JGBs, we cannot obtain data from 17:00 till 9:00 the next day, so we use the difference of ten-year JGB from 17:00 till 9.00 the next day, when the fiscal news are released. For JGB futures, we use the return of JGB futures from (1) 8:45 to 11:00, (2) 12:30 to 15:00 and (3) 15:30 to 5:00, which gives maximum coverage.

We also obtain the intraday data of stock return and foreign exchange from Bloomberg. We use Nikkei 225 Futures as the Japanese stock index and USD/JPY as the foreign exchange rate. We use Nikkei 225 Futures instead of TOPIX or Nikkei because the futures market opens much longer 
than Nikkei 225 and TOPIX. Nikkei 225 futures are traded during (1) 8:45-15:15 and (2) 16:305:30. Foreign exchange transactions are conducted in an over-the-counter market; therefore, it is traded 24 hours.

We also rely on Bloomberg to capture the minute by minute news. This source includes many other media with Bloomberg's original news. Table 1 shows the information about the fiscal news index. This table shows that the mean of the fiscal index is -0.9077 , which suggests about $90 \%$ of the fiscal news was negative toward the fiscal condition. This is quite natural because our data covers the period of COVID-19.

\section{Empirical result}

\subsection{Main result}

Baseline estimation based on equation (1)

The regression results based on equation (1) are presented in Table 2. Column (1) in Table 2 provides the result of the regression of 1-minute return of ten-year JGB yield on the fiscal news index and shows that the coefficient of the fiscal news index is negative and statistically significant at the 5\% level. This implies that negative news significantly increases the ten-year JGB yield.

Columns (2), (3), (4) and (5) in Table 2 show the estimation results when we use different intervals of change of the ten-year JGB yield. In Column (2), the dependent variable is the 5minute return of ten-year JGB, which indicates that fiscal news significantly affects the 5-minute return of ten-year JGB at the $10 \%$ level. However, Column (5) shows that the fiscal news does not significantly affect the 60-minute return of ten-year JGB, therefore fiscal news does not have a persistent or consistent effect. 
Table 3 shows the estimation result when we use the return of JGB futures. Column (1) provides the result of the regression of 1-minute return of JGB futures on the fiscal news index, which shows that the coefficient of the fiscal news index is positive and statistically significant at the $10 \%$ level. This implies that negative news significantly drops the return of JGB futures. This is a consistent result in Table 3 since the JGB futures price and yield move inversely. Column (2) to (5) show that fiscal news does not have a significant effect, which is also a consistent result in Table 3.

We also check the credibility of the fiscal news data by checking whether fiscal news affects the return 1-, 2-, 3-, 4-, and 5-minutes before the fiscal news releases. If we see a significant relationship, it may indicate that this fiscal news may have been leaked before the media release. We describe the regression result in the Appendix, but we have no significant relationship except in the 1-minute before case, which suggests no leaked information about our fiscal news index. Please refer to the Appendix for details.

\section{The estimation based on equation (2)}

To check the heterogeneous effect of good and bad fiscal news, we use equation (2) for the estimation. Table 4 shows the estimation result. The dependent variable is the return of ten-year yield shown in the upper panel (i) of Table 4. This result shows that good fiscal news does not affect the return of the ten-year JGB, but bad fiscal news has a positive and significant effect on the return of ten-year yield at the $1 \%$ level (except 15 -minute return). This result suggests that investors care only about negative news.

This result is consistent when we use the return of JGB futures as the dependent variable shown in the lower panel (ii) of Table 4. This table shows that bad fiscal news has a negative and 
significant result on the 1-minute return of JGB futures at the $1 \%$ level while good fiscal news does not have significant results. Bad fiscal news has a negative and significant result on the 5minute return of JGB futures at a $10 \%$ level, although it does not affect 15-, 30-, and 60-minute returns, which is consistent with the result of equation (1).

\subsection{Robustness}

For robustness checks, we conduct regressions with the control variables: stock return and the change in foreign exchange rates. As described above, fiscal news could increase the nominal yield because of the positive effect on the Japanese economy, such as the rise of inflation expectation. Since our analysis is based on intraday data, we add stock return and change as control variables using minute by minute data, in equation (3).

Table 5 shows the estimation result with control variables using ten-year JGB yield as a dependent variable. Column (1) in Table 5 shows the baseline result with a 1-minute return of tenyear JGB. Column (2) shows the estimation result when controlling the return on foreign exchange, where fiscal news negatively and significantly affects the return of ten-JGB yield at a 5\% level. The foreign exchange rate (JPY/USD) has a significantly negative effect on the JGB yield; therefore, when the JPY appreciates, the ten-year JGB tends to increase. Column (3) shows the result when we control for the returns on Nikkei 225 futures, indicating that fiscal news negatively and significantly affects the return of ten-JGB yield at a $1 \%$ level. This column also suggests that stock return does not have a significant effect on ten-year JGB yield. Column (4) shows the results of controlling the return of foreign exchange and Nikkei 225 futures simultaneously, which is still significant at a $10 \%$ level. In this case, stock return has a significant positive effect on the ten-year 
JGB yield; this suggests that the positive effect on the Japanese economy hikes the ten-year JGB yield. Overall, this result is consistent with our baseline result.

Table 6 shows the estimation result with the control variables, when we use the return of JGB futures as a dependent variable. This result is also consistent with our baseline result. Column (1) shows the baseline result when we use the 1-minute return of JGB futures. Colum (2), (3), and (4) indicate the result with the control variables. Especially, Column (3) shows that stock return has a negative and significant effect on the return of JGB futures. This implies that the proxy of the good condition of the Japanese economy has reduced the return of JGB futures and this is consistent with our prediction. Although Column (3) shows an insignificant result, fiscal news has a positive and significant effect on the return of JGB futures at the $10 \%$ level.

\section{Conclusion}

The Japanese government suffers from severe fiscal deficits, but the ten-year JGB yield continues to decline. Economists have even warned the government about the deterioration of fiscal deficit and government debt levels, but the ten-year JGB yield inexplicably continues to decline. Especially, after 1990, the BOJ has tried to lower nominal interest rates, but the ten-year JGB yield still tends to decline while the government stimulates the economy by increasing the government fiscal deficit.

To challenge this relationship, we had to use high-frequency data with fiscal news. Since the Japanese government is the largest spender in the world during the COVID-19 pandemic, this period is an ideal situation to test how fiscal news affects the JGB yield. Taking advantage of minute by minute fiscal news data during this pandemic, we conduct a detailed study to answer 
this question.

We find that negative fiscal news significantly but temporarily increased JGB yield. This result suggests that the JGB is considered as a risk-free asset among the investors, but since the result is significant; we would also recommend to the Japanese government to soundly manage their debt sustainability from a longer perspective. 


\section{Appendix}

There is a possibility that investors are aware of the fiscal news before Bloomberg releases it. Therefore, we use the 1-minute return of JGB futures, 1-, 2-, 3-, 4-, and 5-minutes before the fiscal news release. We only use the return of JGB futures because we can match the minute by minute return perfectly with the data of JGB futures. ${ }^{7}$ Table 7 shows the estimation result. We have a significant result when we use the 1-minute return of JGB futures, 1-minute before the fiscal news is released. This may partly be because Bloomberg news has a delay of capturing the original news data. When we use the 1-minute return of JGB futures, 2-, 3-, 4-, and 5-minute before the fiscal news released, we have insignificant results. This suggests no leak of information before the news releases.

\footnotetext{
${ }^{7}$ As we describe in section 3.2, we cannot obtain data from 17:00 to 9:00 (next day), so we use the difference of the 10-year JGB from 17:00 to 9:00 (next day) when fiscal news is released from 17:00 to 9:00 (next day). Therefore, a lagged return makes no sense when we use 10-year JGB return especially when the news is released after 17:00.
} 


\section{References}

[1]. Ando, M., Furukawa, C., Nakata, D., Sumiya, K. 2020. Fiscal Responses to the COVID19 Crisis in Japan: The First Six Month. National Tax Journal 73(3), 901-926.

[2]. Doi, T., Ihori, T. 2009. The Public Sector in Japan: Past Developments and Future Prospects. Edward Elgar.

[3]. Evans, P. 1985. Do Deficits Produce High Interest Rates? American Economic Review 6887.

[4]. Evans, P. 1986. Are Government Bonds Net Wealth? Evidence for the United States. Economic lnquiry, 551-566.

[5]. Fukui, M., Kikuchi, S., Goalist, C. 2020) Job creation during the COVID-19 pandemic in Japan. Working Paper.

[6]. Hattori, T. 2020. The impact of quantitative and qualitative easing on term structure: Evidence from micro-level data. Economics Letters, 109347.

[7]. Hashimoto, Y., Ito, T. 2010. Effects of Japanese macroeconomic statistic announcements on the dollar/yen exchange rate: High-resolution picture. Journal of the Japanese and International Economies 24(3), 334-354.

[8]. Kameda, K. 2014. Budget deficits, government debt, and long-term interest rates in Japan. Journal of the Japanese and International Economies 32, 105-124.

[9]. Kameda, K. 2019. Fiscal sentiment and long-term interest rates. Working Paper.

[10]. Kikuchi, S., Kitao, S., Mikoshiba, M. 2020. Who Suffers from the COVID-19 Shocks? Labor Market Heterogeneity and Welfare Consequences in Japan. Working Paper.

[11]. Kitchen, J. 1996. Domestic and international financial market responses to Federal 
deficit announcements. Journal of International Money and Finance 15(2), 239-254.

[12]. Miyakawa, D., Oikawa, K., Ueda, K. 2020. Firm exit during the Covid-19 pandemic: Evidence from Japan. Working Paper.

[13]. Nakazawa, M. 2002. Nominal interest rates and economic trends in Japan. Financial Review 66, 43-67, Policy Research Institute, Ministry of Finance, Government of Japan (in Japanese).

[14]. Onji, K., Kameda, K., Akai, N. 2012. Preestablished harmony: The Japanese government's demand for Japanese government bonds. Japan and the World Economy 24(3), 207-214.

[15]. Plosser, C. 1982. Government Financing Decisions and Asset Returns. Journal of Monetary Economics 9, 325-52.

[16]. Quigley, M.R., Porter-Hudak, S. 1994. A new approach in analyzing the effect of deficit annoucements on interest rates. Journal of Money, Credit and Banking 26(4), 894-902.

[17]. Wachtel, P., Young, J., 1987. Deficit announcements and interest rates. American Economic Review 77(5), 1007-1012.

[18]. Watanabe, T., Omori, Y. 2020. Online consumption during the COVID-19 crisis: Evidence from Japan. Covid Economics 32, 208-241. 
Figure 1. Trends of JGB Issues

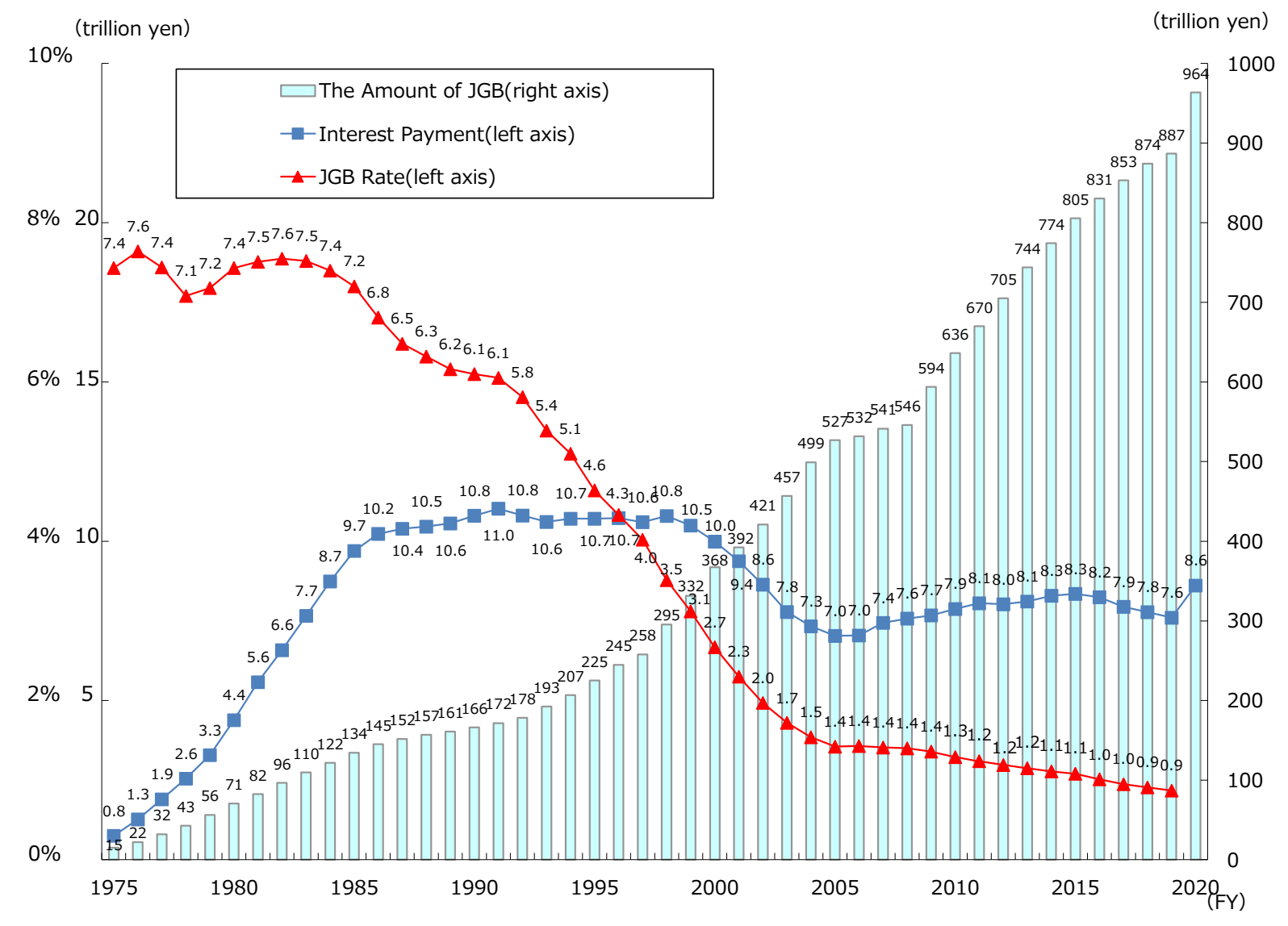

Note: JGB includes “Construction Bonds," "Special Deficit-Financing Bonds,” and "Reconstruction Bonds.” Source: Ministry of Finance, “Financial Statistics in Japan” (in Japanese). 
Figure 2. Process of the Supplementary Budget 
Figure 3. The Actual Schedule of Supplementary Budget for FY2020

First Supplementary Budget

Mar. 28 Prime Minister Declaration

Apr. 7 Decision of the Budget Draft by the

Apr. 20 Decision and Presentation of the Changed Draft by the Cabinet*

Apr. 29 Decision at the Lower House

Apr.30 -Decision at the Upper House -Enactment of the Budget

Source: Bloomberg 
Figure 4. The Scale of Government Spending on COVID-19 Among the G5

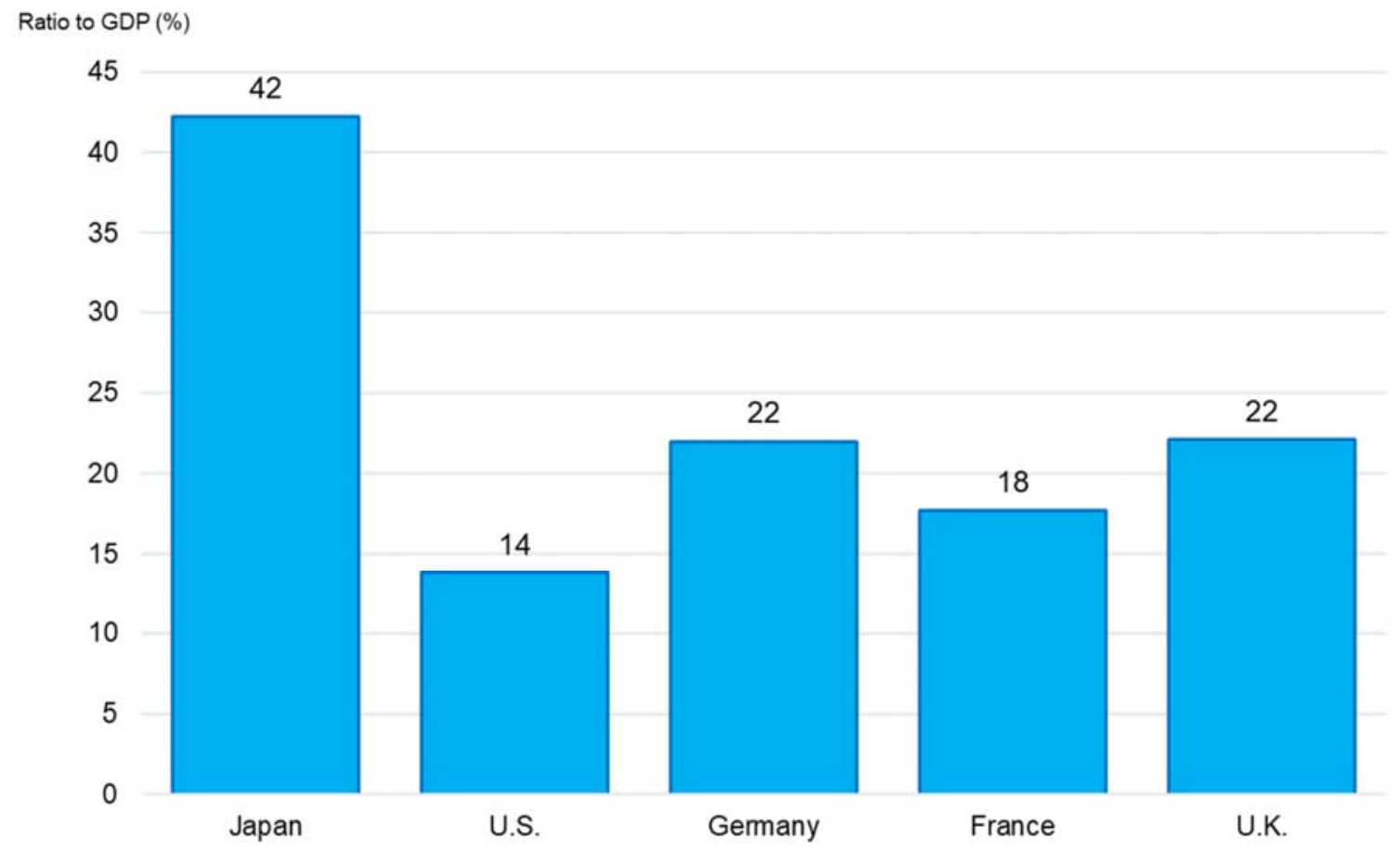

Source: Fiscal System Council, presentation on June 1, 2020 (in Japanese) 
Figure 5. Expenditures and Revenues in the General Account

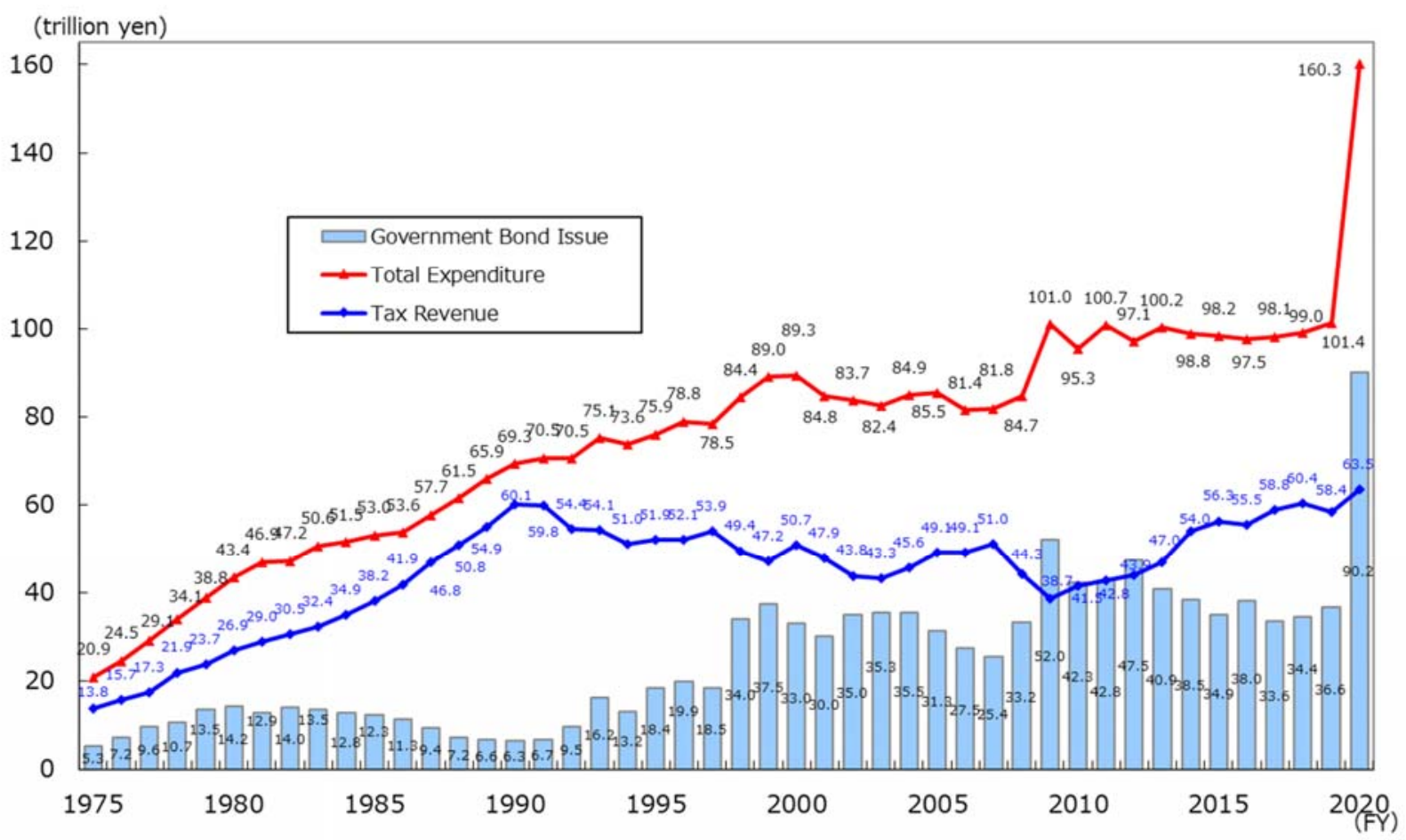

Note: "Government Bond” includes "Construction Bonds" and "Special Deficit-Financing Bonds."

Source: Ministry of Finance, "Financial Statistics in Japan” (in Japanese) 
Figure 6. The Number of Fiscal News Headlines

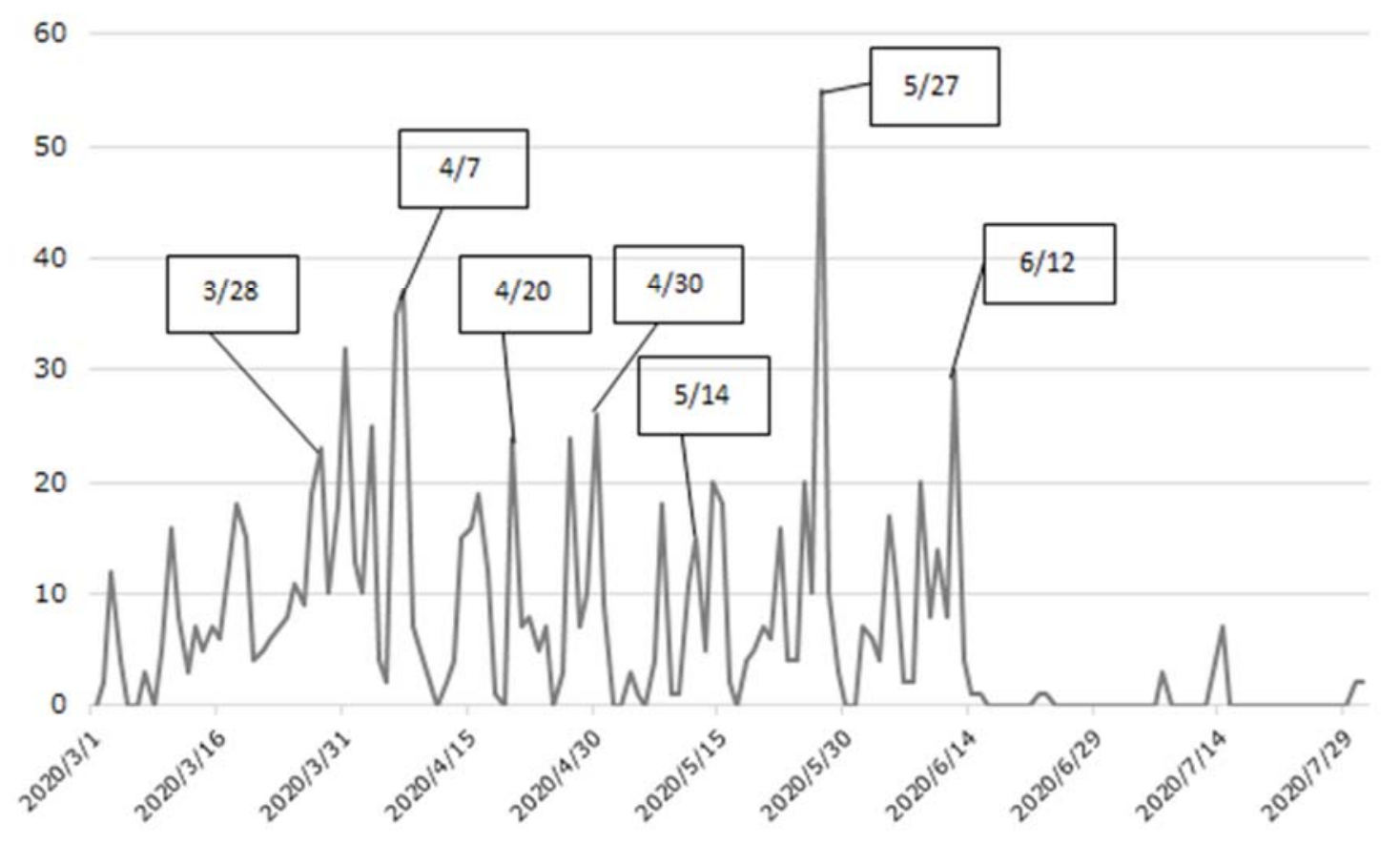

Note: This figure shows the number of fiscal news headlines obtained by Bloomberg. This data is based on minute by minute investigation and showed that fiscal news is concentrated on each day of the critical budget process: Prime Minister's declaration on March 28 and May 14, decision of the budget draft by the Cabinet on April 7 and May 27, decision and presentation of the changed draft by the Cabinet on April 20, and enactment of the budget on April 30 and June 12.

Source: Bloomberg 
Figure 7. Comparison between Headlines during Daytime and Nighttime

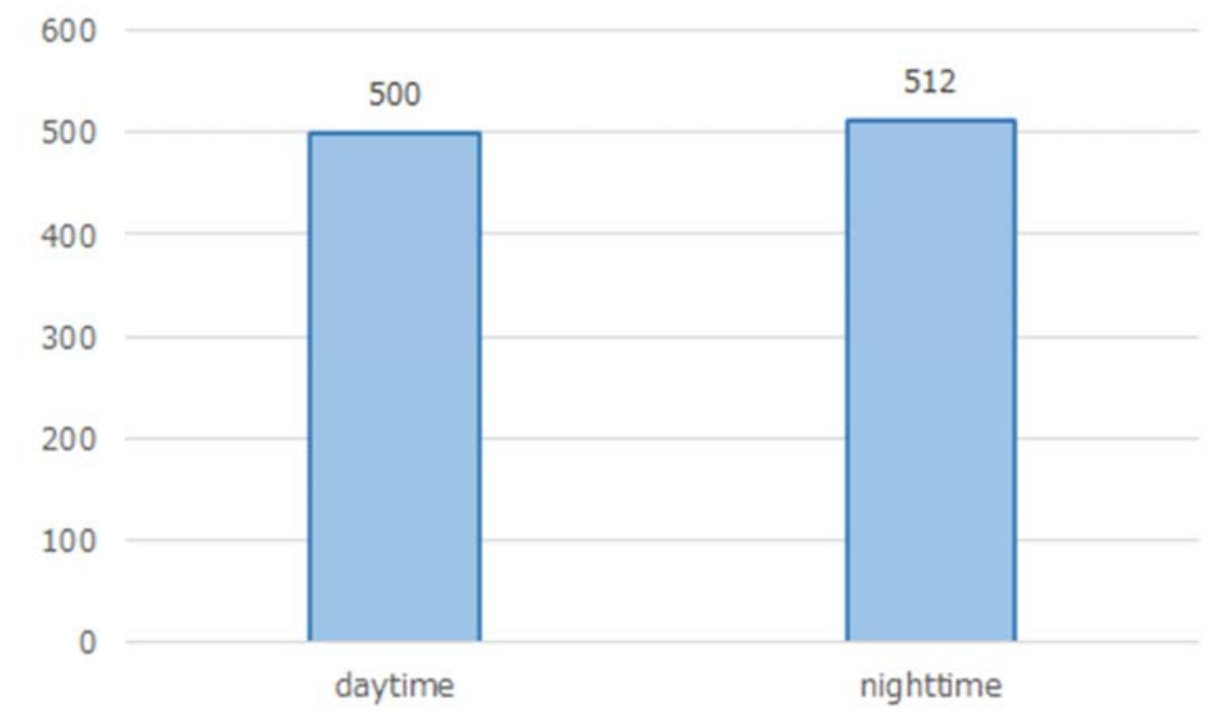

Note: This figure shows the number of fiscal news headlines during daytime and nighttime, obtained by Bloomberg. This data is based on minute by minute investigation and showed that fiscal news is concentrated on each day of the critical budget process

Source: Bloomberg 
Table 1. The information of the fiscal news index

(i) The fundamental statistics about the fiscal news index

\begin{tabular}{cccc}
\hline Mean & Median & Std. Dev. & Observations \\
\hline-0.9077 & -1 & 0.4199 & 1018 \\
\hline
\end{tabular}

(ii) The fiscal news index and JGB return (JGB futures return)

\begin{tabular}{cccccc}
\hline & 1-min & 5-min & 15-min & 30-min & 60-min \\
\hline $\begin{array}{c}\text { Ten-year JGB } \\
\text { fiscal news(negative) }\end{array}$ & 0.000268 & 0.000267 & 0.000163 & 0.000407 & 0.000734 \\
fiscal news(positive) & -0.000149 & -0.000149 & -0.000170 & -0.000596 & -0.000553 \\
& & & & & \\
JGB futures & & & & & \\
$\quad$ fiscal news(negative) & -0.000014 & -0.000017 & -0.000021 & -0.000024 & -0.000071 \\
fiscal news(positive) & 0.000035 & 0.000039 & -0.000027 & 0.000152 & 0.000105 \\
\hline
\end{tabular}

Note: This table shows the fundamental statistics of the fiscal news index. 
Table 2. Estimation result: Ten-year JGB

\begin{tabular}{l|ccccc}
\hline \multirow{4}{*}{ fiscal news } & $\begin{array}{c}1-\mathrm{min} \\
(1)\end{array}$ & $5-\mathrm{min}$ & $15-\mathrm{min}$ & $30-\mathrm{min}$ & $60-\mathrm{min}$ \\
& $-0.0002190 * * *$ & $-0.0001750 *$ & $-0.0004030 *$ & $-0.0005250 * *$ & -0.0006750 \\
& $(-3.31)$ & $(-1.82)$ & $(-1.71)$ & $(-2.06)$ & $(-1.54)$ \\
\hline \hline \multirow{2}{*}{ Constant } & 0.0000697 & 0.0000045 & -0.0002570 & -0.0000703 & 0.0001210 \\
& $(1.06)$ & $(0.05)$ & $(-1.09)$ & $(-0.28)$ & $(0.28)$ \\
\hline \hline R2 & 0.00 & 0.00 & 0.00 & 0.00 & 0.00 \\
obs & 1018 & 1018 & 1018 & 1018 & 1018 \\
\hline
\end{tabular}

Note: This table shows the regression result based on eq. (1). The dependent variable is the return of ten-year JGB yield. The independent variable is the fiscal news index. The period is from March 2020 to July 2020. T-statistics are in parentheses, $*, * *$ and $* * *$ stand for $10 \%, 5 \%$ and $1 \%$ significance, respectively. Standard error is adjusted based on White (1980).

Table 3. Estimation result: JGB futures

\begin{tabular}{l|rrrrr}
\hline & $\begin{array}{c}1-\mathrm{min} \\
(1)\end{array}$ & $5-\mathrm{min}$ & $15-\mathrm{min}$ & $30-\mathrm{min}$ & $60-\mathrm{min}$ \\
& $(2)$ & $(3)$ & $(4)$ & $(5)$ \\
\hline \hline fiscal news & $0.0000245 *$ & 0.0000276 & -0.0000031 & $0.0000879 *$ & 0.0000883 \\
& $(1.86)$ & $(1.58)$ & $(-0.15)$ & $(1.71)$ & $(1.52)$ \\
& & & & \\
Constant & 0.0000104 & 0.0000110 & -0.0000240 & 0.0000637 & 0.0000171 \\
& $(0.80)$ & $(0.63)$ & $(-1.12)$ & $(1.24)$ & $(0.29)$ \\
\hline \hline R2 & 0.00 & 0.00 & 0.00 & 0.00 & 0.00 \\
obs & 462 & 462 & 462 & 462 & 462 \\
\hline
\end{tabular}

Note: This table shows the regression result based on eq. (1). The dependent variable is the return of JGB futures. The independent variable is the fiscal news index. The period is from March 2020 to July 2020. T-statistics are in parentheses, and $*, * *$ and $* * *$ stand for $10 \%, 5 \%$ and $1 \%$ significance, respectively. Standard error is adjusted based on White (1980). 
Table 4. Estimation result: good fiscal news and bad fiscal news

(i) ten-year JGB yield

\begin{tabular}{l|rrrrr}
\hline & 1 -min & $5-$ min & $15-$ min & $30-$ min & $60-m i n$ \\
& $(1)$ & $(2)$ & $(3)$ & $(4)$ & $(5)$ \\
\hline \hline good fiscal news & -0.0001490 & -0.0001490 & -0.0001700 & -0.0005960 & -0.0005530 \\
& $(-1.28)$ & $(-1.28)$ & $(-0.96)$ & $(-1.20)$ & $(-0.66)$ \\
& & & & & \\
bad fiscal news & $0.0002880 * * *$ & $0.0002870 * * *$ & $0.0001790 * *$ & $0.0004550 * * *$ & $0.0007960 * * *$ \\
& $(4.64)$ & $(4.62)$ & $(2.36)$ & $(3.69)$ & $(3.18)$ \\
\hline \hline R2 & 0.00 & 0.00 & 0.00 & 0.00 & \\
obs & 1018 & 1018 & 1019 & 1020 & 1021 \\
\hline
\end{tabular}

(ii) JGB futures

\begin{tabular}{|c|c|c|c|c|c|}
\hline & $\begin{array}{l}1-\min \\
(1)\end{array}$ & $\begin{array}{c}5-\min \\
(2)\end{array}$ & $\begin{array}{r}15-\min \\
(3)\end{array}$ & $\begin{array}{c}30-\min \\
(4)\end{array}$ & $\begin{array}{c}60-\mathrm{min} \\
(5)\end{array}$ \\
\hline good fiscal news & $\begin{array}{r}0.0000349 \\
(1.35)\end{array}$ & $\begin{array}{r}0.0000386 \\
(1.16)\end{array}$ & $\begin{array}{r}-0.0000271 \\
(-0.69)\end{array}$ & $\begin{array}{r}0.0001520 \\
(1.53)\end{array}$ & $\begin{array}{r}0.0001050 \\
(1.01)\end{array}$ \\
\hline bad fiscal news & $\begin{array}{rl}-0.0000140 & * * * \\
(-3.23) & \end{array}$ & $\begin{array}{r}-0.0000166 \\
(-1.66)\end{array}$ & $\begin{array}{r}* \quad-0.0000209 \\
(-1.19)\end{array}$ & $\begin{array}{r}-0.0000243 \\
(-0.95)\end{array}$ & $\begin{array}{r}-0.0000712 \\
(-1.40)\end{array}$ \\
\hline $\begin{array}{l}\text { R2 } \\
\text { obs }\end{array}$ & $\begin{array}{l}0.00 \\
462\end{array}$ & $\begin{array}{l}0.00 \\
462\end{array}$ & $\begin{array}{l}0.00 \\
462\end{array}$ & $\begin{array}{l}0.00 \\
462\end{array}$ & $\begin{array}{l}0.00 \\
462\end{array}$ \\
\hline
\end{tabular}

Note: This table shows the regression result based on eq. (2). The dependent variable is the return of JGB futures. The independent variable is the fiscal news index. The period is from March 2020 to July 2020. T-statistics are in parentheses, and $*, * *$ and $* * *$ stand for $10 \%, 5 \%$ and $1 \%$ significance, respectively. Standard error is adjusted based on White (1980). 
Table 5. Estimation result with controls: ten-year JGB

\begin{tabular}{|c|c|c|c|c|c|c|}
\hline & $\begin{array}{c}\mathrm{a} \\
(1) \\
\end{array}$ & $\begin{array}{c}\mathrm{b} \\
(2)\end{array}$ & & $\begin{array}{c}c \\
(3) \\
\end{array}$ & $\begin{array}{c}d \\
(4)\end{array}$ & \\
\hline fiscal news & $\begin{array}{c}-0.0002190 * * * \\
(-3.31)\end{array}$ & $\begin{array}{r}-0.0001370 \\
(-2.08)\end{array}$ & $* *$ & $\begin{array}{c}-0.0002180 \\
(-3.32)\end{array}$ & $\begin{array}{r}-0.0001410 \\
(-1.98)\end{array}$ & * \\
\hline$\triangle J P Y U S D$ & & $\begin{array}{r}-2.77272 \\
(-11.93)\end{array}$ & $* * *$ & & $\begin{array}{r}-2.87374 \\
(-13.27)\end{array}$ & $* * *$ \\
\hline$\Delta \mathrm{NKY}$ & & & & $\begin{array}{c}-0.03286 \\
(-0.54)\end{array}$ & $\begin{array}{c}0.22759 \\
(3.36)\end{array}$ & $* * *$ \\
\hline Constant & $\begin{array}{c}0.00007 \\
(1.06)\end{array}$ & $\begin{array}{c}0.00007 \\
(1.00)\end{array}$ & & $\begin{array}{c}0.00007 \\
(1.09)\end{array}$ & $\begin{array}{c}0.00005 \\
(0.71)\end{array}$ & \\
\hline $\mathrm{R} 2$ & 0.00 & 0.40 & & 0.00 & 0.41 & \\
\hline obs & 1081 & 1081 & & 1081 & 1081 & \\
\hline
\end{tabular}

Note: This table shows the regression result based on eq. (3). The dependent variable is the return of ten-year JGB yield. The independent variable is the fiscal news index. The period is from March 2020 to July 2020. T-statistics are in parentheses, and $*, * *$ and $* * *$ stand for $10 \%, 5 \%$ and $1 \%$ significance, respectively. Standard error is adjusted based on White (1980)

Table 6. Estimation result with controls: JGB futures

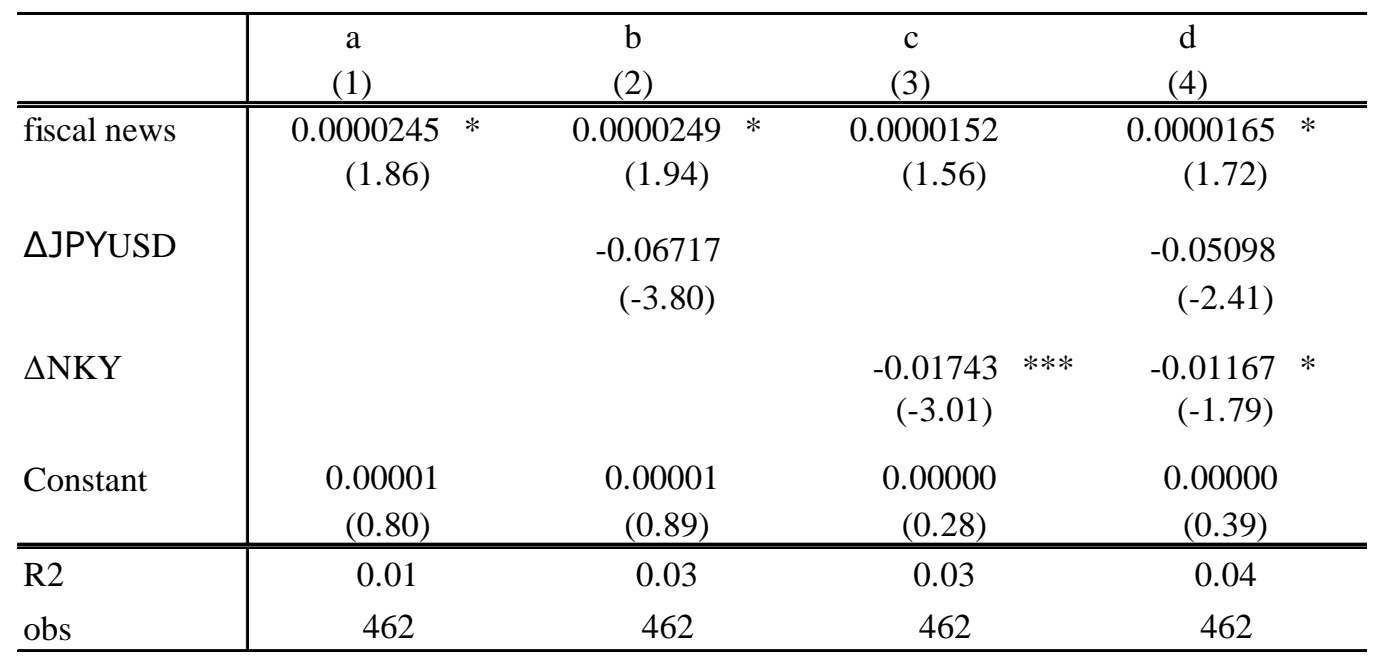

Note: This table shows the regression result based on eq. (3). The dependent variable is the return of JGB futures. The independent variable is the fiscal news index. The period is from March 2020 to July 2020. T-statistics are in parentheses, and $*, * *$ and $* * *$ stand for $10 \%, 5 \%$ and $1 \%$ significance, respectively. Standard error is adjusted based on White (1980) 
Table 7. Estimation result: Lagged return of JGB futures

\begin{tabular}{|c|c|c|c|c|c|}
\hline & $\begin{array}{c}\text { 1-min lag } \\
\text { (1) }\end{array}$ & $\begin{array}{c}\text { 2-min lag } \\
\text { (2) }\end{array}$ & $\begin{array}{r}\text { 3-min lag } \\
\text { (3) }\end{array}$ & $\begin{array}{c}\text { 4-min lag } \\
\text { (4) }\end{array}$ & $\begin{array}{c}\text { 5-min lag } \\
\text { (5) }\end{array}$ \\
\hline fiscal news & $\begin{array}{c}-0.0000127 * * \\
(-1.97)\end{array}$ & $\begin{array}{r}-0.0000091 \\
(-0.82)\end{array}$ & $\begin{array}{r}0.0000055 \\
(0.71)\end{array}$ & $\begin{array}{r}0.0000105 \\
(0.82)\end{array}$ & $\begin{array}{r}0.0000073 \\
(0.93)\end{array}$ \\
\hline Constant & $\begin{array}{r}-0.0000067 \\
(-1.03)\end{array}$ & $\begin{array}{r}-0.0000104 \\
(-0.93)\end{array}$ & $\begin{array}{r}0.0000024 \\
(0.31)\end{array}$ & $\begin{array}{r}0.0000085 \\
(0.66)\end{array}$ & $\begin{array}{r}0.0000083 \\
(1.05)\end{array}$ \\
\hline $\begin{array}{l}\text { R2 } \\
\text { obs }\end{array}$ & $\begin{array}{l}0.00 \\
462\end{array}$ & $\begin{array}{l}0.00 \\
462\end{array}$ & $\begin{array}{l}0.00 \\
463\end{array}$ & $\begin{array}{l}0.00 \\
464\end{array}$ & $\begin{array}{l}0.00 \\
465\end{array}$ \\
\hline
\end{tabular}

Note: This table shows the regression result based on eq. (1). The dependent variable is the return of JGB futures. The independent variable is the fiscal news index. We use the 1-minute return of JGB futures 1-, 2-, 3-, 4-, and 5-minutes before the fiscal news was released. The period is from March 2020 to July 2020. T-statistics are in parentheses, and $*, * *$ and $* * *$ stand for $10 \%, 5 \%$ and $1 \%$ significance, respectively. Standard error is adjusted based on White (1980) 